JoIE: Journal of Islamic Economics | Khoirun Nisak

\title{
Usyur (Bea Cukai) dalam Sistem Perdagangan Internasional Islam Menurut Abu Ubaid dalam Kitab al-Amwal
}

\author{
Khoirun Nisak \\ Institut Agama Islam Negeri Ponorogo, Indonesia \\ khoirunnisak@iainponorogo.ac.id
}

\begin{abstract}
Abstrak: Tujuan penulisan artikel ini adalah untuk menganalisis kajian Abu Ubaid mengenai keuangan publik Islam, khususnya usyur dalam kitab Al-Amwal. Dalam konteks perekonomian hari ini, usyur relevan dengan pembahasan mengenai bea cukai dalam perdagangan internasional. Hampir tidak ada negara yang dapat memenuhi semua kebutuhannya sendiri, sehingga untuk memenuhi kebutuhan yang tidak dapat diproduksi sendiri, sebuah negara harus melakukan perdagangan internasional, melakukan kegiatan ekspor dan impor dengan negara lain. Studi pustaka (library research) digunakan sebagai metode penelitian dengan menggunakan kitab Al-Amwal sebagai rujukan utama, disertai dengan referensi pendukung yang relevan. Ketika membahas tentang usyur, Abu Ubaid banyak merujuk pada kebijakan Khalifah Umar bin Khattab karena usyur adalah sumber pendapatan negara pada masa pemerintahan Khalifah Umar.
\end{abstract}

Kata Kunci: usyur, perdagangan internasional, Abu Ubaid, al-amwal

Abstract: The aim of this paper is to examine Abu Ubaid's view of Islamic public finance, particularly ushur, in the book Al-Amwal.In the context of today's economy, the analysis is relevant to the discussion of customs in international trade. Almost no country can meet all of its own needs, so to meet needs that can not be produced on its own, a country must conduct international trade, carry out export and import activities with other countries. Library research is used as a research methods by using the book Al-Amwal as the main reference, accompanied by relevant supporting references. When discussing ushur, Abu Ubaid referred to many of the policies of Caliph Umar bin Khattab because ushur was a source of state revenue during the reign of Caliph Umar.

Keywords: ushur, international trade, Abu Ubaid, al-amwal

\section{PENDAHULUAN}

Perdagangan internasional adalah perdagangan antar negara yang melintasi batas-batas suatu negara. Salah satu aktivitas perekonomian yang tidak dapat dilepaskan dari perdagangan internasional adalah aktivitas aliran modal, karena 
terjadinya perpindahan faktor-faktor produksi dalam kegiatan ekspor impor (Safitriani, 2014). Perdagangan internasional telah lama dikenal dan dijalankan sepanjang sejarah peradaban manusia. Jauh sebelum teori perdagangan internasional ditemukan di Barat, Islam telah menerapkan konsep-konsep perdagangan internasional. Bahkan kaum Quraisy juga telah mengenal perdagangan internasional sebelum Islam datang. Mata pencaharian pokok kabilahkabilah utama di Jazirah Arab adalah berdagang. Mereka berdagang sampai ke Yaman, Syam, dan Mesir (Al-Mubarakfuri, 2013).

Rasulullah SAW juga memanfaatkan masa muda sebelum kenabiannya dengan melakukan perdagangan Internasional. Rasulullah sudah diajak Abu Thalib berdagang sampai ke Syam pada usia 12 tahun. Kemudian melanjutkan karier berdagangnya secara mandiri ke Syam untuk menjualkan barang-barang dagangan Khadijah. Sehingga perdagangan internasional telah dikenal dengan baik dalam dunia Islam.

Beberapa dasar tekstual yang menguatkan urgensi perdagangan internasional dan peranannya dalam mempermudah perkembangan ekonomi, di antaranya bahwa Allah memberikan bangsa Quraisy kemampuan melakukan perdagangan dengan negara-negara tetangga yang terdapat dalam Al-Qur'an surat Quraisy 1-2: “Karena kebiasaan orang-orang Quraisy; (yaitu) kebiasaan mereka bepergian pada musim dingin dan musim panas." Orang Quraisy melakukan perdagangan ke negeri Syam pada musim panas dan ke Yaman pada musim dingin (Al-Haritsi, 2003).

Sementara Ibnu Khaldun membahas satu bab khusus tentang ekspor dan impor dalam Muqaddimah (2011). Menurut Ibnu Khaldun, perdagangan internasional adalah salah satu sarana untuk mengakumulasi laba dalam jumlah yang besar. Hal tersebut bisa dijelaskan melalui dua mekanisme. Pertama, para pedagang hanya akan mengekspor barang-barang yang berkualitas tinggi yang diminati banyak orang ke negara lain. Sehingga barang tersebut akan dijual dengan harga yang mahal. Kedua, pengiriman barang ke negara lain yang jaraknya jauh juga melewati berbagai risiko dalam perjalanan. Sehingga hanya sedikit orang yang mau mengambil risiko tersebut, yang mengakibatkan barang yang diekspor juga 
JoIE: Journal of Islamic Economics | Khoirun Nisak

sedikit dan akan menyebabkan harga barang menjadi mahal sesuai hukum penawaran dan permintaan.

Dalam perdagangan internasional atau kegiatan ekspor dan impor dikenal istilah bea cukai. Secara definisi bea diartikan sebagai pungutan yang dibebankan atas perbuatan yang berkaitan dengan lalu lintas barang, sedangkan cukai adalah pungutan negara yang dibebankan terhadap barang-barang tertentu dengan sifat dan karakteristik yang perlu dibatasi dan diawasi pemakaiannya sesuai dengan ketentuan perundang-undangan (Ananti, 2017). Khazanah ilmu ekonomi Islam menyebut bea cukai dengan istilah usyur. Salah satu ilmuan Muslim yang berperan besar dalam membahas konsep usyur adalah Abu Ubaid dalam kitabnya Al-Amwal. Sehingga artikel ini akan membahas pandangan Abu Ubaid tentang usyur dan penerapannya dalam perdagangan internasional.

\section{TINJAUAN LITERATUR}

Ilmu ekonomi modern mencatat dua pemikiran besar tentang perdagangan internasional. Yaitu teori keunggulan mutlak yang dicetuskan oleh Adam Smith (1723-1790 M) dan teori keunggulan komparatif yang digagas oleh David Ricardo (1772-1823 M). Menurut Adam Smith suatu negara akan mengeskpor barang tertentu karena negara tersebut bisa menghasilkan barang tersebut dengan biaya yang secara mutlak lebih murah dibandingkan negara lain, yaitu karena memiliki keunggulan mutlak dalam produksi barang tersebut. Keunggulan mutlak merupakan kemampuan suatu negara untuk menghasilkan barang dan jasa per unit dengan menggunakan sumber daya yang lebih sedikit dibanding kemampuan negara lain.

Sedangkan David Ricardo menyatakan bahwa perdagangan internasional dapat terjadi walaupun suatu negara tidak memiliki keunggulan absolut. Berbeda dengan teori keunggulan absolut Adam Smith, Ricardo menjelaskan bahwa perdagangan internasional dapat saling menguntungkan jika salah satu negara tidak memiliki keunggulan absolut, cukup dengan memiliki keunggulan komparatif pada harga untuk suatu komoditi yang relatif berbeda (Helpman, 2010). 
Jauh sebelum Adam Smith dan David Ricardo mengemukakan teori mereka tentang perdagangan internasional, telah ada lebih dulu seorang ilmuwan Muslim yang membahas tentang perdagangan internasional dengan konsep yang menyeluruh, yaitu Abu Ubaid Al-Qasim bin Salam dalam kitab Al-Amwal. Pengertian harfiah Al-Amwal secara bahasa adalah harta. Akan tetapi pembahasan Al-Amwal hanya spesifik pada harta keuangan publik (Islamic Public Finance), dan bukan konsep harta secara umum. Pembahasan mengenai harta keuangan publik dinilai lebih banyak manfaatnya karena berkaitan dengan hak warga negara dalam mendapatkan manfaat ataupun menerima pembagian harta keuangan publik tersebut berdasarkan ketentuan syariah.

Al-Amwal adalah salah satu buku yang ditulis oleh Abu Ubaid Al-Qasim bin Salam bin Miskin bin Zaid (157 H / 774 M - 224 H - 838 M). Abu Ubaid telah mencintai ilmu pengetahuan sejak kecil. Semasa muda Abu Ubaid belajar kepada banyak guru yang menguasai berbagai disiplin ilmu. Abu Ubaid terkenal di kota Baghdad setelah mulai menulis beberapa kitab dan mengajarkan salah satu kitabnya, Gharib al-Hadits yang membahas tentang kata-kata sulit dalam Bahasa Arab. Penguasaan Abu Ubaid dalam beberapa cabang ilmu pengetahuan diakui oleh para ulama masa berikutnya (Suharto, 2004).

Al-Amwal banyak membahas tentang keuangan publik Islam serta dijadikan rujukan dalam mendiskusikan pemikiran ekonomi Islam. Kitab AlAmwal yang tergolong buku klasik pertama dalam khazanah perekonomian Islam memiliki keutamaan dibanding dengan buku klasik ekonomi Islam lainnya, karena Al-Amwal berisi kumpulan hadits dan atsar para sahabat yang berhubungan dengan harta keuangan publik yang pernah dilakukan oleh Nabi Muhammad SAW dan para sahabat. Sehingga Al-Amwal menjadi pijakan dasar dan sumber utama para ekonom Muslim kontemporer.

Keuangan publik yang kini telah berkembang menjadi sebuah disiplin tersendiri dalam ilmu ekonomi modern pada dasarnya dipahami sebagai studi tentang perpajakan dan kebijakan pengeluaran belanja pemerintah, meliputi barangbarang publik, analisis untung-rugi, transfer, beban pajak, keadilan distributif dan kesejahteraan (Suharto, 2004). Secara khusus wacana keuangan publik dalam Al- 
Amwal lebih menekankan pada aspek normatif dalam keuangan publik, karena masalah ini dianggap sebagai bagian dalam hukum Islam.

Terdapat beberapa kajian yang membahas tentang pemikiran Abu Ubaid yang tertuang dalam Al-Amwal. Salah satunya adalah (Ismail \& Jaafar, 2015). Kajian mereka berfokus pada analisis seputar sumber pendapatan negara yang disebutkan Abu Ubaid dalam Al-Amwal, yaitu fai', jizyah, kharaj, dan usyur dan relevansinya dengan pendapatan pemerintah Malaysia. (Suharto, 2004) dalam bukunya yang berjudul Keuangan Publik Islam: Reinterpretasi Zakat dan Pajak membuat kompilasi pembahasan yang menarik mengenai konsep Abu Ubaid dalam keuangan publik Islam. Amwal yang merupakan tema utama karya Abu Ubaid tidak semata dipahami sebagai kekayaan atau hak milik secara umum, tetapi dikhususkan pada kekayaan atau hak milik yang diatur oleh pemerintah untuk kepentingan rakyat. Inilah yang dinamakan kekayaan publik. Suatu kekayaan khusus, di mana pemerintah berhak mengatur dan mengelolanya, bahkan mendistribusikannya kepada masyarakat.

Kajian yang dilakukan oleh (Safitri \& Fakhri, 2017) menganalisis perbandingan pemikiran Abu Ubaid dan Adam Smith mengenai perdagangan internasional. Safitri menyimpulkan bahwa dalam perdagangan internasional, menurut Abu Ubaid diperlukan intervensi pemerintah sebagai mekanisme untuk menerapkan hukum Al-Qur'an dan Sunnah. Abu Ubaid tidak menempatkan peran pemerintah dalam bentuk intervensi sebagai kapitalisme atau sosialisme tetapi sebagai tugas amr ma'ruf nahi munkar yang harus berorientasi pada keadilan bersama dan kesejahteraan sosial, termasuk semua kebijakan dan peraturan yang digunakan oleh pemerintah. Sedangkan menurut Adam Smith, dalam konsep ekspor impor di dalam perdagangan internasional peran pemerintah harus diminimalisirkan bahkan sampai tidak diperlukan. Intervensi pemerintah tidak diperlukan karena ekonomi hanya diserahkan pada kekuatan pasar. Adanya intervensi pemerintah justru menjadi hambatan dalam mewujudkan tujuan ekonomi, yaitu tercapainya kebebasan pasar, serta tidak adanya hambatan terutama dalam perdagangan internasional. 
Perdagangan internasional Abu Ubaid tidak bisa dilepaskan dari konsep usyur. (Hidayati, 2018) menulis artikel tentang perbedaan usyur dan jizyah dalam kajian ekonomi Islam. Keduanya merupakan sumber pendapatan pada awal Islam yang cukup penting untuk keuangan negara. Usyur merupakan harta perdagangan yang diambil dari ahli dzimmah dan ahli harbi yang melewati perbatasan negara Islam. Dalam konteks perekonomian modern, usyur identik dengan pajak eksporimpor atau bea cukai.

\section{METODE PENELITIAN}

Penelitian ini menggunakan pendekatan penelitian kualitatif. Menurut Moleong (1989), penelitian kualitatif dimanfaatkan untuk beberapa keperluan di antaranya adalah untuk lebih dapat memahami setiap fenomena yang belum banyak diketahui oleh orang dan digunakan untuk meneliti sesuatu secara mendalam.

Dalam meneliti, penelitian ini menggunakan studi pustaka (library research). Studi pustaka merupakan studi komprehensif yang dilakukan dengan mempelajari dokumen tulis dan bentuk artifak lain yang relevan. Penelusuran demikian harus dilakukan untuk mendapatkan gambaran yang utuh dari sebuah objek studi (Sawarjuwono, 2013). Studi pustaka dalam penelitian ini menggunakan jurnal dan buku-buku yang membahas tentang perdagangan internasional dan usyur secara mendalam. Salah satu buku utama yang digunakan adalah kitab Al-Amwal yang ditulis oleh Abu Ubaid. Kitab ini merupakan salah satu kitab klasik yang banyak digunakan oleh ekonom Islam dalam membedah teori-teori ekonomi. Di dalam Al-Amwal, Abu Ubaid menjelaskan secara rinci mengenai usyur, disertai juga dengan ayat Al-Qur'an dan hadits Rasulullah yang berhubungan dengan topik bahasan.

\section{HASIL DAN PEMBAHASAN}

\section{Dasar-dasar Perdagangan Internasional dalam Islam}

Islam memperbolehkan umatnya melakukan kegiatan ekonomi, termasuk di dalamnya berdagang baik dengan sesama umat Islam maupun non Islam, selama perdagangan tersebut tidak melanggar nilai-nilai syariat. Perdagangan juga tidak 
dibatasi dalam negeri, tetapi boleh sampai ke mancanegara. Supaya kegiatan ekspor impor dapat mewujudkan kemanfaatan sebesar mungkin bagi kaum muslimin serta meminimalisir mudarat yang mungkin terjadi, maka hubungan tersebut harus memenuhi kaidah-kaidah berikut (Al-Haritsi, 2003):

1. Kehalalan barang dan jasa yang diperdagangkan

Barang dan jasa yang diperjual-belikan antara negara Islam dengan dunia luar harus mubah menurut syariat, karena tidak diperbolehkan membawa masuk barang dan jasa yang diharamkan syariat ke negara Islam. Umat Islam tidak diperbolehkan menjual barang yang haram (misal khamr dan babi) meskipun barang tersebut diekspor ke negara-negara dengan penduduk mayoritas non Islam. Demikian pula, negara Islam tidak diperkenankan menerima impor barang-barang haram.

Pada masa kekhalifahan Umar bin Khattab, kaum non Islam dilarang berjualan khamr dan babi di wilayah Muslim. Jika ada penduduk yang kaya karena berjualan khamr, maka gubernurnya diperintahkan untuk memusnahkan khamr tersebut.

Adanya pelarangan perdagangan barang-barang yang bertentangan dengan syariat ini bertujuan untuk menyesuaikan fungsi konsumsi dan produksi. Jika suatu produk haram untuk dikonsumsi, maka produk tersebut tidak boleh diimpor maupun diproduksi. Karena itu tidak diperbolehkan memproduksi atau mengimpor segala sesuatu, kemudian dikatakan kepada manusia, "Janganlah kamu mengkonsumsinya!".

Tujuan selanjutnya adalah bahwa pembatasan perdagangan barang haram dari luar negeri akan berdampak pada penjagaan akidah umat dan akhlaknya. Pada hari ini mayoritas pasar-pasar di negara Islam dipenuhi dengan barang-barang yang tidak sesuai dengan akhlak kaum muslimin. Sehingga kaum muslimin perlahan-lahan melakukan hal-hal yang dilarang oleh syariat.

2. Perdagangan internasional harus membawa kemaslahatan bagi umat Islam Dibolehkannya melakukan kegiatan ekspor impor antara umat Islam dengan non Islam bukan berarti membuka kesempatan dilakukannya hubungan ekonomi tanpa memastikan adanya kemaslahatan yang kuat bagi umat Islam. 
Kemaslahatan ini salah satu parameternya adalah adanya kesempatan ekspor produksi yang melimpah dari negara Islam atau mengimpor barang yang sangat dibutuhkan umat Islam.

3. Ekspor impor dengan negara Islam sebagai prioritas

Di antara manfaat terpenting dari adanya hubungan dagang dengan negaranegara Islam adalah merealisasikan kemandirian ekonomi bagi kaum muslimin dan mengikis sikap pengekoran ekonomi Islam terhadap ekonomi non Islam. Dengan demikian, akan terjalin hubungan yang saling menguntungkan antar negara-negara Islam sehingga saling membawa maslahat antara kedua belah pihak. Sehingga dalam perdagangan internasional, negara Islam yang melakukan kegiatan impor ekspor tetap harus menjadikan sesama negara Islam sebagai prioritas partner berdagangnya.

Umar bin Khattab sangat antusias untuk menguatkan ikatan antara wilayahwilayah Islam pada waktu makmur maupun paceklik. Ketika terjadi paceklik di Hijaz, maka Umar mengirim surat ke wilayah-wilayah Islam lain untuk meminta bantuan bagi saudara-saudara yang membutuhkan tersebut. Lalu wilayah yang berkecukupan dengan senang hati mengirimkan bantuan kepada Hijaz tanpa ada imbalan apapun. Hal ini sesuai dengan Al-Qur' an surat At-Taubah ayat 71, "Dan orang-orang yang beriman, laki-laki dan perempuan, sebagian mereka (adalah) menjadi penolong bagi sebagian yang lain."

4. Perjanjian perdagangan

Membuat akad kesepakatan dagang antar negara yang disepakati oleh kedua belah pihak merupakan hal yang tidak dapat dihindari untuk meminimalisir adanya salah satu pihak yang dirugikan. Perjanjian dagang yang dilakukan pemerintah Islam dengan non muslim seharusnya memenuhi dasar-dasar sebagai berikut: Harus terdapat kemaslahatan yang kuat bagi kaum muslimin, dan poin-poin kesepakatan tidak boleh mencakup hal yang diharamkan menurut syariah, seperti akad riba, ekspor impor barang haram, atau segala sesuatu yang menimbulkan mudharat bagi negara Islam. 
JoIE: Journal of Islamic Economics | Khoirun Nisak

\section{Bea Cukai dalam Perdagangan Internasional}

Dalam kegiatan ekspor impor, selalu ada biaya yang dikenakan untuk pedagang karena melintasi perbatasan negara lain, yang dalam ekonomi hari ini disebut dengan bea cukai. Bea cukai dalam Islam disebut dengan istilah usyur. Usyur adalah apa yang diambil oleh petugas negara dari harta yang dipersiapkan untuk dagang ketika melintasi negara Islam (Al-Haritsi, 2003).

Usyur dipungut atas seluruh barang dagangan yang melintasi batas wilayah suatu negara. Apapun jenisnya, termasuk perhiasan, hasil pertanian, buah-buahan, maupun hewan ternak. Usyur tidak diambil dari pakaian atau peralatan yang digunakan oleh seseorang untuk kegiatannya, atau kebutuhan sehari-hari, termasuk makanan. Jika ada seseorang yang mengadukan bahwa barang yang dibawa ketika melintasi perbatasan negara itu bukan untuk diperdagangkan, padahal barang tersebut untuk diperdagangkan, maka pernyataan tersebut tidak dipercaya kecuali dengan menghadirkan bukti-bukti untuk memastikan kebenaran pengaduannya (Hidayati, 2018).

Abu Ubaid dalam kitabnya Al-Amwal banyak membahas tentang perdagangan internasional termasuk di dalamnya tentang cukai (Tanjung, 2010). Pemikiran Abu Ubaid tentang bea cukai dapat dibagi menjadi tiga bagian, yaitu: tidak adanya nol tarif dalam perdagangan internasional, cukai bahan makanan lebih murah, dan ada batas tertentu untuk dikenakan cukai.

\section{Tidak Adanya Nol Tarif}

Pada awalnya pengumpulan cukai merupakan tindakan yang dilarang. Terdapat beberapa hadits tentang haramnya pengumpulan cukai. Dari Uqbah bin Amir bahwa dia pernah mendengar Rasulullah bersabda, "Pengumpul cukai barang impor tidak akan masuk ke dalam surga." . Dari Abul Khair bahwa Ruwaifa bin Tsabit pernah mendengar Rasulullah bersabda, "Sesungguhnya pengumpul zakat atas barang impor berada dalam neraka." Yang dimaksud dengan pengumpul zakat atas barang impor adalah para pengumpul cukai barang impor. Dari Abdullah bin Amru, dia berkata, "Sesungguhnya pengumpul cukai tidak akan ditanyakan mengenai amalnya sedikitpun, sebagaimana dia mengambil cukai ketika di alam dunia, maka dia langsung dicampakkan ke dalam api neraka." 
Hadits lain diriwayatkan dari Abdurrahman bin Ma'qil, ia berkata, "Saya pernah bertanya kepada Ziyad bin Hudair, 'Siapakah yang telah kalian pungut cukai barang impornya?' Ia berkata, “kami tidak pernah mengenakan cukai atas muslim dan mu'ahid.' Saya bertanya, 'Lantas siapakah orang yang telah engkau kenakan cukai atasnya?' Ia berkata, 'Kami mengenakan cukai atas para pedagang kafir harbi, sebagaimana mereka telah memungut barang impor kami apabila kami masuk dan mendatangi negeri mereka."”

Umar bin Abdul Aziz telah mengirim sepucuk surat kepada Adi in Artha'ah yang isinya adalah. "Biarkanlah bayaran fidyah manusia. Biarkanlah bayaran makan kepada ummat manusia. Hilangkanlah bayaran cukai barang impor atas umat manusia. Sebab, ia bukanlah cukai barang sebagaimana firman Allah, "Dan janganlah kamu merugikan manusia terhadap hak-hak mereka dan jangan kamu membuat kejahatan di bumi dengan berbuat kerusakan." (Q.S Hud : 85) (Ubaid, 2009).

Hal tersebut diperjelas lagi dengan surat-surat Rasulullah yang dikirimkan kepada penduduk penjuru negeri seperti Tsaqif, Bahrain, Dawmatul Jandal dan lainnya yang telah memeluk agama Islam. isi surat tersebut adalah, "Binatang ternak mereka tidak boleh diambil dan barang dagangan impor mereka tidak boleh dipungut cukai atasnya."

Dari uraian di atas, Abu Ubaid mengambil kesimpulan bahwa pengumpulan cukai pada mulanya adalah kebiasaan pada zaman jahiliyah dan telah dilakukan oleh raja bangsa Arab dan non Arab tanpa pengecualian. Sebab kebiasaan mereka adalah memungut cukai barang dagangan impor atas harta mereka, apabila masuk ke dalam negeri mereka. Kemudian Allah membatalkan sistem cukai tersebut dengan diutusnya Rasulullah dan agama Islam. Lalu datanglah kewajiban membayar zakat sebanyak seperempat dari usyur (2,5\%). Dan pada setiap dua ratus dirham maka zakatnya adalah lima dirham. Barangsiapa yang telah mengambilnya sesuai dengan kadar kewajiban zakat, maka ia tidak dinamakan dengan pengumpul cukai. Sebab ia tidak mengambil usyur, namun mengambil seperempat dari usyur.

Ini adalah sebagai penjelasan terhadap hadits, bahwa Rasulullah pernah bersabda, "Tidak ada kewajiban membayar cukai (usyur) atas kaum muslimin. 
JoIE: Journal of Islamic Economics | Khoirun Nisak

Akan tetapi, ia hanya diberlakukan kepada bangsa Yahudi dan pemeluk agama Nasrani saja."

Maka hadits yang telah disebutkan di atas, tentang keharaman memungut cukai yang dimaksudkan menurut Abu Ubaid adalah, "Apabila seseorang telah memungut lebih dari bayaran zakat yang semestinya, maka ia telah mengambil zakat yang tidak berdasarkan kepada haknya.” Demikian pula dengan hadits yang diriwayatkan oleh Ibnu Umar ketika ditanya, "Apakah engkau pernah mengetahui bahwa Umar pernah mengambil cukai usyur dari kaum muslimin?" Ibnu Umar menjawab,’Tidak pernah. Saya tidak mengetahui secara pasti mengenai hal itu."

Menurut Abu Ubaid, Umar bin Khattab menginginkan pengumpulan cukai 1/10 dari barang impor dan dia tidak menginginkan dalam hadits tersebut pengumpulan zakat. Umar bin Khattab dan khalifah yang lain tidak mungkin mengingkari kewajiban cukai karena mereka telah mengambil cukai sebagai dana pembayaran gaji. Pendapat Ibnu Umar di atas bermaksud pengumpulan cukai dan kemudian diserahkan kepada penerimaan gaji.

Apabila pengumpul cukai telah mengambil zakat dari harta kaum muslimin dengan syarat mereka telah menyerahkan zakat itu secara sukarela tanpa adanya peperangan, maka yang demikian itu tidak termasuk dalam keterangan-keterangan hadits di atas. Namun jika pengumpul cukai telah memaksa kaum muslimin, maka yang demikian itu termasuk ke dalam kategori hadits di atas. Maka penetapan usyur merupakan ijtihad dari Khalifah Umar bin Khattab di hadapan para sahabat dan tidak ada seorang sahabat pun yang menyanggahnya sehingga merupakan ijma (konsensus). Umar merupakan orang pertama yang menetapkan usyur di dalam Islam dengan membuat rincian hukumnya, membuat teknis pelaksanaannya, mengangkat para pegawai yang menanganinya, dan hal-hal lainnya yang berhubungan.

Gagasan Abu Ubaid tentang pendapatan publik ini sebenarnya dilandaskan pada penafsiran Khalifah Umar bin Khattab. Dengan demikian Abu Ubaid mendasarkan pendapatnya tentang pendapatan publik pada tafsiran Umar. Karena itu diperhatikan keseluruhan struktur buku Al-Amwal yang disusun secara sistematis, maka Abu Ubaid dapat dianggap sebagai orang yang berpegang pada 
pendapat Umar bin Khattab mengenai pendapatan publik dalam Islam. Abu Ubaid karena itu dapat dianggap sebagai ulama yang telah berjasa karena yang pertama kali menyusun pendapat Khalifah Umar ke dalam sebuah bentuk wacana yang lengkap (Suharto, 2004).

Dalam buku "Fikih Ekonomi Umar bin Khattab" disebutkan bahwa besar usyur yang ditetapkan adalah 2.5\% dari umat Islam, 5\% dari ahli dzimmah, dan $10 \%$ dari ahli harbi. Namun sesungguhnya penetapan usyur sangat fleksibel sesuai dengan kebijakan yang diambil pemerintah. Pemerintah dapat menaikkan usyur atas barang-barang yang kurang bermanfaat dan bahkan memiliki potensi untuk merusak, sebaliknya pemerintah dapat menurunkan tariff usyur atas barang-barang yang dibutuhkan dan membawa kemaslahatan besar bagi kaum muslimin.

Dari Ziyad bin Hudair, ia berkata, "Saya telah dilantik Umar menjadi petugas bea cukai. Lalu dia memerintahkanku supaya mengambil cukai barang impor dari para pedagang ahli harbi sebanyak usyur (10\%), barang impor pedagang ahli dzimmah sebanyak setengah dari usyur (5\%), dan barang impor pedagang kaum muslimin seperempat dari usyur (2,5\%)." Jika ditarik ke dalam kondisi hari ini, banyak penganut perdagangan bebas (free trade) yang mengatakan bahwa cukai merupakan salah satu bentuk merugikan orang lain. Seharusnya tidak ada tarif barrier pada suatu negara. Barang dagangan harus bebas masuk dan keluar dari suatu negara. Dengan kata lain, bea masuknya nol persen. Tetapi, dalam konsep Islam, tidak ada sama sekali yang bebas, meskipun barang impor itu adalah barang kaum muslimin (Tanjung, 2010). Adanya tarif ini salah satunya untuk melindungi pasar dan produsen dalam negeri supaya tidak dibanjiri barang-barang impor. Dalam kondisi yang melebihi batas, impor berlebihan malah akan mematikan produsen dalam negeri jika mereka tidak siap berkompetisi dengan barang-barang impor. Maka seharusnya pemerintah bertindak bijaksana dengan tetap mengenakan tarif cukai dalam impor, terutama negara-negara berkembang.

\section{Cukai Bahan Makanan Pokok}

Islam menetapkan bahwa cukai atas bahan makanan tidak sama tarifnya dengan cukai barang dagang lainnya. Cukai yang dikenakan bukan $10 \%$ atau $5 \%$ 
dengan tujuan agar barang impor berupa makanan pokok banyak berdatangan ke Madinah sebagai pusat pemerintahan saat itu.

Tentang hal ini, Abu Ubaid menulis dalam Al-Amwal sebuah hadits dari Salim bin Abdullah bin Umar dari ayahnya, ia berkata, "Umar telah memungut cukai dari kalangan pedagang luar, masing-masing dari minyak dan gandum dikarenakan bayaran cukai sebanyak seperlima. Hal ini bertujuan sepaya barang impor terus berdatangan ke negeri Madinah. Dan, dia telah memungut cukai dari barang impor al-Qithniyyah sebanyak usyur (10\%)."

Bahan makanan merupakan hal yang sangat krusial dibutuhkan oleh masyarakat. Jika tarif impornya rendah, maka akan banyak bahan makanan yang masuk ke dalam negara sehingga ketahanan pangan negara tersebut tidak perlu dikhawatirkan lagi. Pada saat Madinah terkena paceklik, maka Umar bin Khattab juga pernah impor gandum dari Mesir dengan tarif cukai yang rendah. Akan tetapi cukai bahan makanan pokok ini harus diimplementasikan dengan adil supaya membawa kesejahteraan sosial bagi masyarakat, terutama petani dalam negeri. Impor bahan makanan pokok memang selayaknya harus dilakukan jika stok bahan makanan pokok produksi petani dalam negeri tidak mencukupi kebutuhan masyarakat atau terdapat kondisi khusus yang mengharuskan pemerintah untuk impor bahan makanan pokok, sebagaimana kebijakan yang dilakukan oleh Khalifah Umar bin Khattab ketika Madinah paceklik. Namun impor bahan makanan pokok akan menjadi kontradiktif jika produksi petani dalam negeri sebenarnya bisa mencukupi kebutuhan pangan masyarakat. Sehingga impor bahan makanan pokok harus ada pembatasan. Jika tidak ada pembatasan, impor bahan makanan pokok diperkirakan akan terus meningkat seiring dengan peningkatan jumlah penduduk, peningkatan pendapatan masyarakat, dan pertumbuhan industri pengolahan makanan.

Pemerintah perlu melakukan pengaturan dan pembatasan impor bahan pangan. Kebijakan impor ini bertujuan untuk melindungi petani agar menerima harga layak dan sekaligus melindungi konsumen supaya dapat membeli pangan dengan harga terjangkau. Sehingga tercipta kesejahteraan bagi petani dan masyarakat (Erwidodo, tanpa tahun). 
JoIE: Journal of Islamic Economics | Khoirun Nisak

\section{Ada Batas Tertentu untuk Cukai}

Selain lebih rendahnya tarif bagi bahan makanan, tidak semua barang dagangan juga dipungut cukainya. Ada batas-batas tertentu dimana kalau kurang dari batas minimal yang ditentukan, maka cukai tidak akan dipungut. Hal ini disebutkan dalam hadits yang diriwayatkan dari Ruzaiq bin Hayyan ad-Damisyqi (dia adalah petugas cukai di perbatasan Mesir pada saat itu) bahwa Umar bin Abdul Aziz telah menulis surat kepadanya, yang isinya adalah, "Barangsiapa yang melewatinya dari kalangan ahli dzimmah, maka pungutlah barang dagangan impor mereka. Yaitu, pada setiap dua puluh dinar mesti dikenakan cukai sebanyak satu dinar. Apabila kadarnya kurang dari jumlah tersebut, maka hitunglah dengan kadar kekurangannya, sehingga ia mencapai sepuluh dinar. Apabila barang dagangannya kurang dari sepertiga dinar, maka janganlah engkau memungut apa pun darinya. Kemudian buatkanlah surat pembayaran cukai kepada mereka bahwa pengumpulan cukai akan tetap diberlakukan sehingga sampai satu tahun."

Jumlah sepuluh dinar adalah sama dengan jumlah seratus dirham di dalam ketentuan pembayaran zakat. Seorang ulama Irak, Sufyan telah menggugurkan kewajiban membayar cukai apabila barang impor ahli dzimmah tidak mencapai seratus dirham. Menurut Abu Ubaid, seratus dirham inilah ketentuan kadar terendah pengumpulan cukai atas harta impor ahli dzimmah dan ahli harbi (Tanjung, 2010).

Adapun perkataan para ulama mengenai seorang ahli dzimmah yang mengaku bahwa dia mempunyai tanggung jawab untuk membayar utang dan seluruh hartanya hanya untuk pembayaran utang, maka terdapat dua pendapat apakah orang tersebut tetap wajib membayar usyur atau tidak. Ulama Irak menyatakan bahwa boleh menerima pengakuannya tersebut dan tidak wajib untuk membayar usyur, walaupun dia tidak memiliki bukti yang dapat memperkuat perkataannya. Sedangkan ulama Hijaz menyatakan bahwa pengakuan tersebut tidak dapat diterima dan tetap dikenakan pembayaran usyur, walaupun dia memiliki dalil dan bukti yang dapat membenarkannya (Ubaid, 2009).

Sedangkan menurut pendapat Abu Ubaid, apabila ahli dzimmah tersebut memiliki saksi dari kaum muslimin bahwa dia benar-benar memiliki utang, maka pengakuan tersebut diterima dan hartanya tidak dikenakan usyur. Sebab, utang 
merupakan hak wajib yang mesti dibayar kepada orang yang memberikan pinjaman kepadanya. Oleh karena itu membayar utang lebih diutamakan dibanding membayar usyur.

Pengecualian terhadap barang impor yang pernah dibahas oleh Abu Ubaid ini juga berlaku pada negara-negara dalam konteks hari ini. Indonesia misalnya juga terdapat pembebasan bea masuk dan cukai. Yaitu terhadap barang pribadi penumpang dengan nilai pabean paling banyak FOB USD 500,00 per orang untuk setiap kedatangan, diberikan pembebasan bea masuk (www.beacukai.do.id)

Usyur hanya dipungut satu kali dalam setahun untuk satu jenis komoditas perdagangan, meskipun pedagang tersebut berkali-kali melewati perbatasan negara lain dengan membawa komoditas perdagangannya tersebut. Maka petugas cukai tidak boleh memungut lebih dari satu kali. Adapun jika para pedagang ahli dzimmah membawa barang dagangan yang berbeda ketika melewati batas negara, maka ia tetap diwajibkan membayar usyur (Ubaid, 2009).

\section{KESIMPULAN}

Islam memperbolehkan adanya perdagangan internasional dan tindakan muamalah lainnya asalkan tidak melanggar syariat, tidak mengandung unsur-unsur haram, maysir, dan riba. Perdagangan internasional yang dilakukan oleh negara Islam juga harus dilakukan dengan tujuan supaya menguntungkan negara tersebut, bukan malah membuat negara dan rakyatnya tidak dapat berdaulat karena berhutang budi dengan negara lain.

Usyur merupakan konsep yang tidak bisa dilepaskan dalam pembahasan mengenai perdagangan internasional. Usyur, pajak yang dikumpulkan dari para pedagang di kalangan ahli dzimmah, atau barang impor dari pada pedagang ahli harbi. Abu Ubaid dalam Al-Amwal telah banyak menjelaskan bahwa pada mulanya usyur tidak diterapkan dalam Islam, dan Rasulullah mengutuk para pengumpul cukai. Namun karena pedagang Muslim dikenakan cukai ketika masuk ke dalam negara non Islam, akhirnya Umar bin Khattab membuat ijtihad diberlakukannya usyur kepada pedagang ahli harbi dan ahli dzimmah sebagai bentuk keadilan. 
JoIE: Journal of Islamic Economics | Khoirun Nisak

Penjelasan Abu Ubaid mengenai keuangan publik dalam kitab Al-Amwal banyak banyak yang disandarkan pada penafsiran Khalifah Umar bin Khattab. Keseluruhan struktur buku Al-Amwal yang disusun Abu Ubaid secara sistematis, membuatnya dianggap sebagai orang yang berpegang pada pendapat Umar bin Khattab mengenai pendapatan publik dalam Islam. Abu Ubaid karena itu dapat dianggap sebagai ulama yang telah berjasa karena yang pertama kali menyusun pendapat Khalifah Umar ke dalam sebuah bentuk wacana yang lengkap

\section{REFERENSI}

Admin Web Bea dan Cukai. (2013). Impor. https://www.beacukai.go.id/arsip/pab/impor.html. Diakses pada 2 Juli 2021

Al-Haritsi, Jaribah bin Ahmad. (2003). Fikih Ekonomi Umar bin Khattab. Jakarta: Pustaka Al-Kautsar

Al-Mubarakfuri, Shafiyurrahman. (2013). Sirah Nabawiyah. Depok: Gema Insani Press

Al-Qasim, Abu Ubaid. (2009). Al-Amwal (Ensiklopedia Keuangan Publik). Depok: Gema Insani Press

Ananti, Ridha. (2017). Konsep Pajak Menurut Abu Yusuf dan Relevansinya pada Masa Sekarang. http://www.klinikpajak.co.id/berita+detail/?id=berita+pajak++konsep+pajak+menurut+abu+yusuf+dan+relevansinya+pada+masa+sekara ng. Diakses pada 29 April 2021

Erwidodo. (tanpa tahun). Kebijakan Impor, Cadangan Pangan, Stabilisasi Harga dan Ketahanan Pangan Nasional Berkemandirian. Laporan Litbang Kementerian Pertanian

Helpman, Elhanan. (2010). Unequal Effects of Trade on Workers with Different Abilities. Journal of European Economic Association, Volume 8, Issue 2-3, 1 May 2010, Pages 421-433

Hidayati, Nurul. (2018). 'Usyur dan Jizyah dalam Kajian Ekonomi Islam. Tawazun: Journal of Sharia Economic Law, Volume 1, Nomor 1, Maret 2018 
JoIE: Journal of Islamic Economics | Khoirun Nisak

Ismail, AG., \& Jaafar, AB. (2015). Government Revenue in the Eyes of Abu Ubaid. International Journal of Asian Social Science, 2015, 5(1): 1-17

Khaldun, Ibnu. (2011). Muqaddimah. Jakarta: Pustaka Al-Kautsar

Moleong, L.J. (1989). Metodologi Penelitian Kualitatif. Bandung: PT Remaja Rosdakarya

Safitri, J., \& Fakhri, A. (2017). Analisis Perbandingan Pemikiran Abu Ubaid AlQasim dan Adam Smith Mengenai Perdagangan Internasional. Millah: Jurnal Studi Agama, Vol. xvii, No. 1 (2017), PP. 85-98

Safitriani, Suci. (2014). Perdagangan Internasional dan Foreign Direct Investment di Indonesia. Jurnal Ilmiah Litbang Perdagangan, Vol 8 No 1 Juli 2014, hal. 93-116

Sawarjuwono, Tjiptohadi. (2013). Workshop Panduan Penelitian Kualitatif. Disampaikan dalam seminar di Universitas Muhammadiyah Surakarta 21 Desember 2013

Suharto, Ugi. (2004). Keuangan Publik Islam: Reinterpretasi Zakat dan Pajak. Yogyakarta: Pusat Studi Zakat

Tanjung, Alfian. (2010). Abu Ubaid dan Perdagangan Internasional. Iqtishodia Jurnal Ekonomi Islam Republika, September 2010 